\title{
Antimicrobial activity of Gynura segetum's leaf extracts and its active fractions
}

\author{
Lay-Jing Seow*, Hooi-Kheng Beh, Pazilah Ibrahim, Amirin Sadikun, Mohd Zaini Asmawi \\ School of Pharmaceutical Sciences, Universiti Sains Malaysia, Penang, Malaysia
}

\begin{abstract}
Gynura segetum (Lour.) Merr. (Compositae) is a well recognized medicinal plant in Indonesia and Malaysia. It is believed to have an anticoagulant effect and is used in treating snake-bites, inflammations and other skin afflictions. This study was carried out to evaluate the antimicrobial effects of Gynura segetum leaves extracts and its fractions. The chemical compositions of the active extracts were also determined. The antimicrobial activities of different solvent extracts of leaves of Gynura segetum were evaluated using the agar well-diffusion method. The Minimum Inhibitory Concentration (MIC) of the active subfractions was determined by the tube dilution method. Gas Chromatography-mass spectrometry (GC-MS) analysis was carried out to identify the chemical compositions of the active extracts. The ethyl acetate fraction and its subfraction E4 performed potent antimicrobial activities and fifteen known chemical constituents were identified by GCMS analysis as 4-vinylphenol, 1-tetradecene, phenol, 2,4bis(1,1-dimethylethyl), 1-hexadecene, E-15-heptadecenal, hexadecanoic acid, 1,2-benzenedicarboxylic acid, dibutyl ester, 1-docosene, octadecanoic acid, 1-eicosene, cyclotetracosane, 1,2-benzenedicarboxylic acid, bis(2-ethylhexyl)ester, butanedioic acid, monomethyl ester, niacin and 4-hydroxy-benzoic acid. The results of this study suggested a connection between the antimicrobial activities and the chemical structures. The plant may be used as a potential source for antimicrobial agents.
\end{abstract}

Keywords agar well-diffusion, antimicrobial, gas chromatography-mass spectrometry, Gynura segetum, minimum inhibitory concentration

\section{INTRODUCTION}

Serious infections caused by bacteria that have become resistant to commonly used antibiotics have become a major global healthcare problem in the 21st century (He and Zhou, 2007). Plants have long provided mankind with herbal remedies for many infectious diseases, and even today they continue to play a major role in primary health care as therapeutic remedies in developing countries (Tshikalange et al., 2005).

Natural products, either as pure compounds or as standardized plant extracts, provide unlimited opportunities for new drug leads because of the unmatched availability of chemical diversity (Parekh and Chanda, 2007). Therefore, researchers have growing interests in using natural antimicrobial compounds, especially those extracted from plants. Up to the present, many herbs and phytochemicals have been shown to have antimicrobial activities, e.g. Soymida febrifuga leaf extracts (Reddy et al., 2008), Viguiera arenaria root (Porto et al., 2009), Coriandrum sativum L. (Begnami et al., 2010), Vismia rubescens stem bark (Tamokou et al., 2009), Acacia mellifera (Mutai et al., 2009), Cocos nucifera L. (Esquenazi et al., 2002) and Cleistocalyx operculatu (Dung et al., 2008)

Gynura segetum (Lour.) Merr. (Daun Dewa in malay), which belongs to family Compositae, is a well recognized medicinal plant in Indonesia and Malaysia and is believed to

\footnotetext{
*Correspondence: Lay-Jing Seow

E-mail: layjing80@gmail.com

Received March 12, 2012; Accepted May 22, 2012; Published May

31,2012

doi: http://dx.doi.org/10.5667/tang.2012.0010

(C) 2012 by Association of Humanitas Medicine

TANG / www.e-tang.org
}

have anticoagulant effects. It is used for treating snake-bites, inflammations and other skin afflictions (Yuan, 1990). In Malaysia, the use of this plant is restricted to only the traditional healers and the Malays consumed it as a vegetable (ulam). In Indonesia, the leaves and rhizome are considered to have medicinal value for both internal and external use. This herb can be combined with other medicinal plants to treat cancer, diabetes and hypertension. It is used externally for the treatment of bleeding wounds, bruises, boils and sores, septic nails and ulcerous wounds. The fresh rhizome is crushed and applied externally on the wounds caused by the bites of wild animal. The mixture of powdered rhizome with aloe vera is useful for treating burns and scalds. It is consumed as a vegetable (ulam) among local people. Leaves are consumed either raw, as salad, or cooked. Juice of the leaves mixed with carrot and tomato is a popular cooling drink (Suharmiati \& Maryani, 2003). In China, G. segetum is widely used for several applications. This plant is claimed to have anticoagulant effects used for treating snake-bite, inflammation, and other skin afflictions (Yuan et al., 1990). Decoction of the roots is used to relieve heat, while decoction of the leaves is used to treat coughing. The powder of G. segetum's dried leaves is applied externally on diseased parts for an early cure and it is claimed to be very effective in reducing the swelling on the body in Chinese medicine.

In the present study, the antimicrobial effects of $G$. segetum leaf extracts and fractions were evaluated using the agar diffusion method. The chemical composition in active extracts was identified by Gas Chromatography-mass spectrometry (GC-MS) analysis.

\section{MATERIALS AND METHODS}

2012 / Volume 2 / Issue 2 / e20 


\section{Plant Material}

The leaves of the plants were collected from Jabatan Pertanian Relau, Penang and identified by Mr. Adenan Jaafar, a taxonomist from the School of Biological Sciences, University Sains Malaysia. A voucher sample of the plant, reference number 11013 was deposited at the herbarium of School of Biological Sciences, University Sains Malaysia.

\section{Preparation of leaves extracts and fractions}

Freshly collected leaves were dried in an oven at about $45^{\circ} \mathrm{C}$ and ground to fine powder. The powdered leaves $(700 \mathrm{~g})$ were first extracted with petroleum ether $\left(60-80^{\circ} \mathrm{C}\right)$ for 3 days, followed by chloroform and finally with methanol using a Soxhlet apparatus. The extracts were evaporated in a rotary evaporator at a maximum temperature of $45^{\circ} \mathrm{C}$ to yield $93.03 \mathrm{~g}$ $(13.29 \%)$ of petroleum ether extract, $107.38 \mathrm{~g}$ (15.34\%) of chloroform extract and $150 \mathrm{~g}(21.48 \%)$ of methanol extract.

The methanolic extract $(30 \mathrm{~g})$ was dissolved in $300 \mathrm{ml}$ hot distilled water and then partitioned successively with equal volumes $(300 \mathrm{ml} \times 3)$ of chloroform $\left(\mathrm{CHCL}_{3}\right)$, ethyl acetate (EA), and n-butanol $(\mathrm{BuOH})$ by a liquid-liquid extraction method. All these partitions were separately concentrated under reduced pressure to yield $2.91 \mathrm{~g}(9.71 \%)$ of $\mathrm{CHCL}_{3}$ fraction, $9.45 \mathrm{~g}(31.5 \%)$ of EA fraction, and $5.82 \mathrm{~g}(19.4 \%)$ of $\mathrm{BuOH}$ fraction.

\section{Microbial Strains}

The microorganisms were obtained from the stock culture of the Microbiology Laboratory of the School of Pharmaceutical Sciences, Universiti Sains Malaysia. Six species of bacteria: Staphylococcus aureus, Bacillus subtilis, Enterobacter aerogenes, Pseudomonas aeruginosa, Escherichia coli, Proteus mirabilis, and yeast, Candida albicans were used in this study.

\section{Preparation of test samples}

The petroleum ether extract, chloroform extract, methanol extract, chloroform fraction, ethyl acetate fraction, and butanol fraction were dissolved in $2 \%(\mathrm{v} / \mathrm{v})$ dimethyl sulfoxide (DMSO) and tested at a concentration range from $50 \mathrm{mg} / \mathrm{ml}$ to $6.25 \mathrm{mg} / \mathrm{ml}$. Gentamicin (Sigma, Aldrich) was used as positive reference standards for bacteria and amphotericin B (Sigma, Aldrich) for yeast, obtained from Sigma-Aldrich, Germany.

\section{Antimicrobial screening of the leaf extracts of Gynura segetum}

The antimicrobial screening of the leaf extracts of G. segetum was carried out by the agar well-diffusion method as described by Khan et al. (2000) with some modifications. A single colony of cells from the stock cultures grown on the agar plate were suspended in a sterile nutrient broth, then shaken to obtain an even inoculum suspension. The mixtures were incubated for 24 $\mathrm{h}$ at $37^{\circ} \mathrm{C}$ for the bacteria and at $25^{\circ} \mathrm{C}$ for yeast, respectively.

The turbidity of the inoculum was then adjusted to a standard solution, McFarland 0.5 which is equivalent to $1.5 \times$ $10^{6}$ cells per $\mathrm{ml}$. One $\mathrm{ml}$ of this inoculum was inoculated into a bottle of 1 litre nutrient agar. The mixture was shaken gently to obtain an even suspension. The agar mixture was then poured in $20 \mathrm{ml}$ amounts into petri dishes $(9 \mathrm{~cm}$ in diameter) and allowed to solidify at room temperature. When the agar was solidified, 4 wells ( $6 \mathrm{~mm}$ diameter each) were made in each of these plates using a sterile cork borer. Seventy $\mu 1$ of the test samples was applied into each well. The same volume of blank $(2 \%$ DMSO) was run as a blank control. After a diffusion time of $2 \mathrm{~h}$ at room temperature, the plates were incubated at $37^{\circ} \mathrm{C}$ for $24 \mathrm{~h}$ for the bacteria and at $25^{\circ} \mathrm{C}$ for 3 days for yeast.

Antimicrobial activity was evaluated by measuring the diameter (millimeters) of the zone of growth inhibition produced around the wells. All tests were performed in triplicate and the average values of antimicrobial activity were calculated. The results were expressed as average values \pm S.D.

The level of antimicrobial activity was interpreted based on Puroit et al. (2003) with some modifications: Low = inhibition zone $12 \mathrm{~mm}$ or less; Moderate $=$ inhibition zone is greater than $12 \mathrm{~mm}$ but smaller than $20 \mathrm{~mm}$; High = inhibition zone is greater than $20 \mathrm{~mm}$.

\section{Fractionation of the active extract for antimicrobial screening}

Based on antimicrobial screening results, the ethyl acetate fraction was found to be the most active and therefore subjected to further fractionation. The ethyl acetate fraction was subjected to dry-flash chromatography [silica gel $\mathrm{GF}_{254}$ ] with chloroform-ethyl acetate-methanol as the eluent with the increasing polarity.

New sub-fractions (E1 to E15) obtained from the ethyl acetate fraction were tested for their antimicrobial activities at a concentration range from $5 \mathrm{mg} / \mathrm{ml}$ to $0.625 \mathrm{mg} / \mathrm{ml}$. The same method as mentioned in session 2.5 was repeated. The experiments were repeated three times and the results were expressed as average values \pm S.D.

\section{Minimum Inhibitory Concentration (MIC) determinations of the active samples}

The MIC was determined only for samples found active (E2-E7 and E14) in the initial screening by the diffusion method described above. A tube dilution method (Kuete et al., 2007) was used to determine the MIC with some modifications. The test samples were prepared in $2 \%$ of DMSO and then serial dilutions of test samples with DMSO were made in a concentration range from 5 to $0.125 \mathrm{mg} / \mathrm{ml}$ for active subfractions and 10 to $0.0625 \mu \mathrm{g} / \mathrm{ml}$ for gentamicin. The tubes were incubated for $24 \mathrm{~h}$ at $37^{\circ} \mathrm{C}$. The lowest concentration

Table 1. Inhibition zones ${ }^{\mathrm{a}}(\mathrm{mm})$ of ethyl acetate fraction of Gynura segetum's leaf and reference antibiotics

\begin{tabular}{|c|c|c|c|c|c|}
\hline \multirow{3}{*}{ Test microorganisms } & \multicolumn{5}{|c|}{ Diameter of zone inhibition (mm) } \\
\hline & \multicolumn{4}{|c|}{ Ethyl acetate fraction $(\mathrm{mg} / \mathrm{ml})$} & \multirow{2}{*}{ Reference antibiotics $^{\mathrm{b}}$} \\
\hline & 50 & 25 & 12.5 & 6.25 & \\
\hline Staphylococcus aureus & $20.0 \pm 1.0$ & $13.0 \pm 1.0$ & - & - & $25.0 \pm 1.0$ \\
\hline Bacillus subtilis & $18.3 \pm 1.2$ & $12.7 \pm 0.6$ & $10.7 \pm 0.6$ & $8.3 \pm 0.6$ & $29.3 \pm 0.6$ \\
\hline Enterobacter aerogenes & $13.0 \pm 1.0$ & $9.7 \pm 0.6$ & - & - & $28.1 \pm 0.6$ \\
\hline Pseudomonas aeruginosa & $23.3 \pm 2.0$ & $19.0 \pm 1.0$ & $14.3 \pm 1.2$ & $11.3 \pm 0.6$ & $19.0 \pm 0.6$ \\
\hline Escherichia coli & $17.0 \pm 1.0$ & $11.0 \pm 1.0$ & - & - & $34.3 \pm 0.6$ \\
\hline Proteus mirabilis & $20.7 \pm 0.6$ & $14.3 \pm 1.2$ & $9.3 \pm 0.6$ & - & $39.1 \pm 1.0$ \\
\hline Candida albicans & $13.0 \pm 1.0$ & $8.7 \pm 0.6$ & - & - & $15.3 \pm 0.6$ \\
\hline
\end{tabular}

${ }^{\mathrm{a}}$ Including the diameter of the hole $(6 \mathrm{~mm})$

${ }^{\mathrm{b}}$ Reference antibiotics (Gentamicin (50 ppm) for bacteria; Amphotericin B (500 ppm) for yeast) 
Table 2. Inhibition zones ${ }^{\mathrm{a}}(\mathrm{mm})$ for the ethyl acetate subfractions of Gynura segetum's leaf

\begin{tabular}{|c|c|c|c|c|c|c|c|c|c|c|c|c|c|}
\hline \multirow{3}{*}{$\begin{array}{c}\text { Test } \\
\text { microorganisms }\end{array}$} & \multicolumn{13}{|c|}{ Diameter of zone $^{\mathrm{b}}$} \\
\hline & \multirow{2}{*}{ E2 } & \multicolumn{2}{|c|}{ E3 } & \multicolumn{3}{|c|}{ E4 } & \multicolumn{2}{|c|}{ E5 } & \multicolumn{2}{|c|}{ E6 } & \multicolumn{2}{|c|}{ E7 } & \multirow{2}{*}{$\frac{\text { E14 }}{\mathrm{A}}$} \\
\hline & & $\mathbf{A}$ & B & $\mathbf{A}$ & B & $\mathbf{C}$ & $\mathbf{A}$ & B & $\mathbf{A}$ & B & $\mathbf{A}$ & B & \\
\hline Bacillus subtilis & - & $\begin{array}{c}15.3 \pm \\
0.6\end{array}$ & $\begin{array}{c}13.3 \pm \\
0.6\end{array}$ & $\begin{array}{c}12.3 \pm \\
0.6\end{array}$ & $\begin{array}{c}10.3 \pm \\
1.2\end{array}$ & - & $\begin{array}{c}11.3 \pm \\
0.6\end{array}$ & $\begin{array}{c}8.7 \pm \\
0.6\end{array}$ & $\begin{array}{c}10.7 \pm \\
0.6\end{array}$ & - & - & - & - \\
\hline $\begin{array}{c}\text { Pseudomonas } \\
\text { aeruginosa }\end{array}$ & $\begin{array}{l}11.3 \pm \\
0.6\end{array}$ & $\begin{array}{c}14.7 \pm \\
0.6\end{array}$ & - & $\begin{array}{c}10.7 \pm \\
0.6\end{array}$ & $\begin{array}{c}8.0 \pm \\
0.0\end{array}$ & 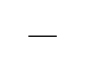 & $\begin{array}{c}12.0 \pm \\
1.0\end{array}$ & - & - & - & - & - & - \\
\hline Escherichia coli & - & $\begin{array}{c}12.0 \pm \\
1.0\end{array}$ & $\begin{array}{c}8.7 \pm \\
0.6\end{array}$ & $\begin{array}{l}11.3 \pm \\
0.6\end{array}$ & $\begin{array}{l}8.7 \pm \\
0.6\end{array}$ & - & - & - & - & - & $\begin{array}{c}12.7 \pm \\
0.6\end{array}$ & $\begin{array}{c}10.7 \pm \\
0.6\end{array}$ & - \\
\hline Proteus mirabilis & - & $\begin{array}{c}16.7 \pm \\
0.6\end{array}$ & $\begin{array}{c}12.3 \pm \\
0.6\end{array}$ & $\begin{array}{c}16.7 \pm \\
1.5\end{array}$ & $\begin{array}{c}14.3 \pm \\
0.6\end{array}$ & $\begin{array}{c}10.3 \pm \\
0.6\end{array}$ & $\begin{array}{c}16.3 \pm \\
1.2\end{array}$ & $\begin{array}{c}12.0 \pm \\
0.0\end{array}$ & $\begin{array}{c}13.3 \pm \\
0.6\end{array}$ & $\begin{array}{c}10.0 \pm \\
1.0\end{array}$ & $\begin{array}{c}11.7 \pm \\
0.6\end{array}$ & $\begin{array}{c}9.7 \pm \\
0.6\end{array}$ & $\begin{array}{c}11.7 \pm \\
1.2\end{array}$ \\
\hline
\end{tabular}

${ }^{\mathrm{a}}$ Including the diameter of the hole $(6 \mathrm{~mm})$

${ }^{\mathrm{b}}$ Tested sample: active ethyl acetate subfractions; concentration of test samples (A, $\left.5 \mathrm{mg} / \mathrm{ml} ; \mathrm{B}, 2.5 \mathrm{mg} / \mathrm{ml} ; \mathrm{C}, 1.25 \mathrm{mg} / \mathrm{ml}\right) ;-$, no inhibition

(highest dilution) of the extract that produced no visible bacterial growth (no turbidity) was regarded as MIC. Three replicates of each micro assay were carried out and the experiment was carried out twice.

Gas Chromatography-mass spectrometry (GC-MS) analysis The GC-MS analysis of the active samples were performed using an Agilent 6890 gas chromatography instrument coupled to an Agilent 5973 mass spectrometer and Agilent ChemStation software (Agilent Technologies, Palo Alto, CA, USA). Compounds were separated on a HP-5MS, $30 \mathrm{~m} \times 0.25 \mathrm{~mm}$ i.d. capillary column coated with $0.25 \mu \mathrm{m}$ film $(5 \%$ phenyl methyl siloxane). The oven temperature was $70^{\circ} \mathrm{C}$ which was held for $2 \mathrm{~min}$, followed by an increase in temperature to $280^{\circ} \mathrm{C}$ and this was held isothermally for $20 \mathrm{~min}$. Helium was used as the carrier gas at a $1.2 \mathrm{ml} / \mathrm{min}$ flow rate. The injector and detector temperatures were $250^{\circ} \mathrm{C}$ and $280^{\circ} \mathrm{C}$, respectively. The parameters of the HP 5973 mass detector were: ion mass/charge ratio, $20-500 \mathrm{~m} / \mathrm{z}$; scan mode and the ionization energy were $70 \mathrm{eV}$. The chemical component in the ethyl acetate fraction and subfraction E4 were identified by comparison of their mass spectra with those of the WILEY/NIST library.

\section{RESULTS}

The antimicrobial activities of leaf extracts of G. segetum were assayed by an agar well-diffusion method against seven microorganisms. To ensure that the solvent had no inhibitory effects on the microorganisms, an appropriate control was carried out simultaneously. The results showed that DMSO $2 \%$ used in these experiments produced no inhibitory effects on the microorganisms.

All concentrations of petroleum ether extracts and chloroform extracts exhibited no antimicrobial activity against the seven microorganisms tested. The methanol extract, chloroform fraction and butanol fractions only showed low activity against $B$. subtilis and $P$. aeruginosa at high concentrations. On the other hand, the strong inhibitory effects of the ethyl acetate fraction were noted. All the tested microorganisms were found to be susceptible to the ethyl acetate fraction at high concentrations $(50 \mathrm{mg} / \mathrm{ml}$ and 25 $\mathrm{mg} / \mathrm{ml}$ ). The results of the antimicrobial activity of the ethyl acetate fractions of $G$. segetum and reference antibiotics against the microorganisms tested are shown in Table 1.

Among the test samples, the ethyl acetate fraction had the greatest potential of antimicrobial activities against all the microorganisms tested. Therefore, further fractionation was carried out. Fifteen sub-fractions (E1 to E15) were obtained and each was tested at concentrations ranging from $5 \mathrm{mg} / \mathrm{ml}$ to $0.625 \mathrm{mg} / \mathrm{ml}$. Only seven out of the fifteen sub-fractions showed antimicrobial effects to some of the microorganisms. The results are summarized in Table 2 (data of inactive sub fractions not shown).

Since the active sub-fractions of ethyl acetate fraction (E2 to E7 and E14) were tested at different concentrations, the real extent of their inhibitory activities against the tested microorganisms could be understood only by comparing the minimum inhibitory concentration (MIC) values. The MIC values obtained are summarized and shown in Table 3 . The lowest MIC obtained was $1.25 \mathrm{mg} / \mathrm{ml}$ for sub-fraction E4 against $E$. coli and $P$. mirabilis. These values were respectively 20 times and 10 times greater than those of the ethyl acetate fraction on E. coli and P. mirabilis.

Upon GC-MS analysis, the chemical compositions and structures of the main constituents from the active ethyl acetate fraction and sub-fraction E4 were identified as shown in Table 4. For the first time our study reports the chemical compositions of the ethyl acetate fraction and its sub-fraction E4 of G. segetum leaves.

\section{DISCUSSION}

Table 3. Minimum inhibitory concentrations of active ethyl acetate sub-fractions ${ }^{\mathrm{a}}$

\begin{tabular}{|c|c|c|c|c|c|c|c|c|}
\hline \multirow{3}{*}{$\begin{array}{c}\text { Tested } \\
\text { microorganisms }\end{array}$} & \multicolumn{8}{|c|}{ Minimum Inhibitory Concentrations } \\
\hline & \multicolumn{7}{|c|}{$(\mathrm{mg} / \mathrm{ml})$} & \multirow{2}{*}{$\begin{array}{c}(\mu \mathrm{g} / \mathrm{ml}) \\
\text { Standard }^{\mathrm{b}}\end{array}$} \\
\hline & E2 & $\mathbf{E 3}$ & $\mathbf{E 4}$ & E5 & E6 & E7 & E14 & \\
\hline Bacillus subtilis & - & 2.50 & 2.50 & 2.50 & 5.00 & - & - & 7.50 \\
\hline $\begin{array}{l}\text { Pseudomonas } \\
\text { aeruginosa }\end{array}$ & 5.00 & 3.75 & 2.50 & 3.75 & - & - & - & $\leq 10.0$ \\
\hline Escherichia coli & - & 1.875 & 1.25 & - & - & 2.50 & - & 0.125 \\
\hline Proteus mirabilis & - & 1.875 & 1.25 & 1.875 & 1.875 & 2.50 & 5.00 & 0.0625 \\
\hline
\end{tabular}

${ }^{\mathrm{a} E} 2$, E3, E4, E5, E6, E7 and E14 are sub-fractions from ethyl acetate fraction, which exhibited active antimicrobial activity against three selected test microorganisms.

${ }^{\mathrm{b}}$ Reference antibiotics (Gentamicin) 
Table 4. Chemical composition of the main constituents from the active ethyl acetate fraction and sub-fraction E4

\begin{tabular}{|c|c|c|c|c|}
\hline \multicolumn{5}{|c|}{ A) The main compounds identified in ethyl acetate fraction } \\
\hline No & Compound & $\begin{array}{l}\text { Retention time } \\
\text { (min) }\end{array}$ & Peak area $(\%)$ & Molecular formula \\
\hline 1) & 4-vinylphenol (1) & 6.19 & 1.70 & $\mathrm{C}_{8} \mathrm{H}_{8} \mathrm{O}$ \\
\hline 2) & 1-Tetradecene (2) & 7.32 & 0.96 & $\mathrm{C}_{14} \mathrm{H}_{28}$ \\
\hline 3) & Phenol, 2,4-bis(1,1-dimethylethyl) (3) & 8.17 & 13.27 & $\mathrm{C}_{14} \mathrm{H}_{22} \mathrm{O}$ \\
\hline 4) & 1-Hexadecene (4) & 8.60 & 7.52 & $\mathrm{C}_{16} \mathrm{H}_{32}$ \\
\hline 5) & E-15-Heptadecenal (5) & 9.74 & 8.99 & $\mathrm{C}_{17} \mathrm{H}_{32} \mathrm{O}$ \\
\hline 6) & Hexadecanoic acid (6) & 10.66 & 5.86 & $\mathrm{C}_{16} \mathrm{H}_{32} \mathrm{O}_{2}$ \\
\hline 7) & 1,2-Benzenedicarboxylic acid, dibutyl ester (7) & 10.69 & 1.76 & $\mathrm{C}_{16} \mathrm{H}_{22} \mathrm{O}_{4}$ \\
\hline 8) & 1-Docosene (8) & 10.77 & 6.95 & $\mathrm{C}_{22} \mathrm{H}_{44}$ \\
\hline 9) & Octadecanoic acid (9) & 11.59 & 2.18 & $\mathrm{C}_{18} \mathrm{H}_{36} \mathrm{O}_{2}$ \\
\hline 10) & 1-Eicosene (10) & 11.71 & 4.41 & $\mathrm{C}_{20} \mathrm{H}_{40}$ \\
\hline 11) & Cyclotetracosane (11) & 12.57 & 2.43 & $\mathrm{C}_{24} \mathrm{H}_{48}$ \\
\hline 12) & 1,2-Benzenedicarboxylic acid, bis(2-ethylhexyl)ester (12) & 13.35 & 1.77 & $\mathrm{C}_{24} \mathrm{H}_{38} \mathrm{O}_{4}$ \\
\hline
\end{tabular}

B) The main compounds identified in subfraction E4

\begin{tabular}{clccc}
\hline No & Compound & $\begin{array}{c}\text { Retention time } \\
\text { (min) }\end{array}$ & Peak area (\%) & Molecular formula \\
\hline 1$)$ & Butanedioic acid, monomethyl ester (13) & 5.52 & 10.18 & $\mathrm{C}_{5} \mathrm{H}_{8} \mathrm{O}_{4}$ \\
$2)$ & Niacin (14) & 6.85 & 8.16 & $\mathrm{C}_{6} \mathrm{H}_{5} \mathrm{NO}_{2}$ \\
$3)$ & Phenol, 2,4-bis(1,1-dimethylethyl) (3) & 8.16 & 1.16 & $\mathrm{C}_{14} \mathrm{H}_{22} \mathrm{O}$ \\
$4)$ & 4-hydroxy-Benzoic acid (15) & 8.66 & 10.61 & $\mathrm{C}_{7} \mathrm{H}_{6} \mathrm{O}_{3}$ \\
5) & Hexadecanoic acid (6) & 10.64 & 0.44 & $\mathrm{C}_{16} \mathrm{H}_{32} \mathrm{O}_{2}$ \\
\hline
\end{tabular}

Results from the initial screening of the plant extracts of $G$. segetum for antimicrobial activity show that the ethyl acetate fraction exhibited the strongest antimicrobial activity against all bacterial and yeast strains tested. Therefore, the ethyl acetate fraction was chosen for further fractionation to identify the most active sub-fraction. The results obtained from the screening showed that the antimicrobial activity was gradually increasing as we moved from the crude extract to fraction and sub-fraction. In addition, the inhibitory effects increased with the increase of the concentrations of test samples. The ethyl acetate fraction had a stronger and broader spectrum of antimicrobial activity as compared to the crude methanol extract.

Our study showed the presence of alkanes, alkenes, aldehyde, fatty acids, phenol, ester and pyridine in the active ethyl acetate fraction and its sub-fraction E4. Some researchers reported that there is a relationship between the chemical structures of the most abundant compounds in the tested samples and the antimicrobial activities (Skočibušić et al., 2006). For example, Vardar-nl et al. (2003) studied the antimicrobial and antioxidant activities of the essential oil and extracts from Thymus pectinatus Fisch. et Mey. var. pectinatus. The results showed that the activity was mainly observed in those fractions containing a high content of thymol, carvacrol and borneol. Similarly, the extract of Satureja hortensis L. had the great potential of antimicrobial activities apparently related to their high phenolic contents, particularly the main components thymol and carvacrolne (Güllüce et al., 2003). In the study conducted by Zhu et al. (2004), the artichoke (Cynara scolymus L.) leaf extracts and the phenolic compounds isolated from the artichoke leaf extract showed antimicrobial activities against a wide range of microorganisms. Among the compounds, chlorogenic acid, cynarin, luteolin-7-rutinoside, and cynaroside had a relatively higher activity than others against all of the tested fungi; in addition, they were more effective against fungi than bacteria.

The chemical structures of the most abundant compounds found in this study were aliphatic chains (long chain alkane and alkene), aromatic compounds and fatty acids. Aliphatic chains (long chain alkane and alkene) were non-polar groups and hydrophobic. Voda et al. (2004) and Kim et al. (2007) suggested that the lipophilicity (hydrophobic) of the molecule was the most important factor for the antimicrobial activities of the compounds, which determine the ability of the compound to penetrate the cell walls of bacteria. On the other hand, the hydroxyl $(\mathrm{OH})$ group of the aromatic compounds and fatty acids could enter the membrane, orient into the aqueous phase by hydrogen bonding and non-polar carbon chain aligned to the lipid phase by dispersion forces. The dispersion forces cause the disturbance of the fluidity of the cell membranes and the growth of the bacteria affected. These results agree with the findings reported in Kubo et al. (1995) which proposed that the antimicrobial activity maybe due to a balance between the polar hydrophilic and nonpolar hydrophobic portions of the molecule.

The whole data obtained from this study suggested that the aliphatic chains and hydroxyl $(\mathrm{OH})$ group correlated with their antimicrobial activities. These findings support the hypothesis that there is a relationship between the chemical structures of the most abundant compounds in the tested samples and the antimicrobial activities as was also reported by Skočibušić et al. (2006). This possibility remains to be tested and further studies of the active constituents of the G. segetum leaves are necessary to determine the possible mechanisms of the compounds.

In conclusion, the ethyl acetate fraction and subfraction E4 performed potent antimicrobial activities. This study suggested a relationship between the chemical structures of the most abundant compounds in the active test samples and the antimicrobial activities. Further studies of the active constituents of the leaves of $G$. segetum will be necessary in order to establish if they could be safely used as antimicrobial agents. 


\section{ACKNOWLEDGEMENT}

The authors acknowledge the financial support given by the Universiti Sains Malaysia (USM). The authors also thank the School of Pharmaceutical Sciences, USM for providing the necessary facilities and excellent technical assistance.

\section{CONFLICT OF INTEREST}

The authors have no conflicting financial interests.

\section{REFERENCES}

Begnami AF, Duarte MCT, Furletti V, Rehder VLG. Antimicrobial potential of Coriandrum sativum L. against different Candida species in vitro. Food Chem. 2010;118:7477.

Dung NT, Kim JM, Kang SC. Chemical composition, antimicrobial and antioxidant activities of the essential oil and the ethanol extract of Cleistocalyx operculatus (Roxb.) Merr and Perry buds. Food Chem Toxicol. 2008;46:3632-3639.

Esquenazi D, Wigg MD, Miranda MMFS, Rodrigues HM, Tostes JBF, Rozental S, Da Silva AJR, Alviano CS. Antimicrobial and antiviral activities of polyphenolics from Cocos nucifera Linn. (Palmae) husk fiber extract. Res Microbiol. 2002;153:647-652.

Güllüce M, Sökmen M, Daferera D, Ağar G, Özkan H, Kartal $\mathrm{N}$, Polissiou M, Sökmen A, Şahin F. In vitro antibacterial, antifungal, and antioxidant activities of the essential oil and methanol extracts of herbal parts and callus cultures of Satureja hortensis L. J Agric Food Chem. 2003;51:3958-3965.

He FJ, Zhou J. A new antimicrobial susceptibility testing method of Escherichia coli against ampicillin by MSPQC. J Microbiol Methods. 2007;68:563-567.

Khan MN, Ngassapa O, Matee MIN. Antimicrobial activity of tanzanian chewing sticks against oral pathogenic microbes. Pharm Biol. 2000;38:235-240.

Kim YM, Farrah S, Baney RH. Structure-antimicrobial activity relationship for silanols, a new class of disinfectants, compared with alcohols and phenols. Int $J$ Antimicrob Agents. 2007;29:217-222.

Kubo I, Muroi H, Kubo A. Structural functions of antimicrobial long-chain alcohols and phenols. Bioorg Med Chem. 1995;3:873-880.

Kuete V, Simo IK, Ngameni B, Bigoga JD, Watchueng J, Kapguep RN, Etoa F, Tchaleu BN, Beng VP. Antimicrobial activity of the methanolic extract, fractions and four flavonoids from the twigs of Dorstenia angusticornis Engl. (Moraceae). J Ethnopharmacol. 2007;112:271-277.
Mutai C, Bii C, Vagias C, Abatis D, Roussis V. Antimicrobial activity of Acacia mellifera extracts and lupane triterpenes. J Ethnopharmacol. 2009;123:143-148.

Parekh J, Chanda SV. In vitro Antimicrobial Activity and Phytochemical Analysis of Some Indian Medicinal Plants. Turk J Biol. 2007;31:53-58

Porto TS, Furtado NAJC, Heleno VCG, Martins CHG, Da Costa FB, Severiano ME, Silva AN, Veneziani RCS, Ambrósio SR. Antimicrobial ent-pimarane diterpenes from Viguiera arenaria against Gram-positive bacteria. Fitoterapia. 2009;807:432-436.

Purohit SS, Saluja AK, Kakrani HN. Pharmaceutical Microbiology. (Jodhpur, India: Agrobios), pp 478-482, 2003.

Reddy BS, Reddy BP, Raghavulu SV, Ramakrishna S, Venkateswarlu Y, Diwan PV. Evaluation of Antioxidant and Antimicrobial Properties of Soymida febrifuga Leaf Extracts. Phytother Res. 2008;22:943-947.

Skočibušić M, Bezić N, Dunkić V. Phytochemical composition and antimicrobial activities of the essential oils from Satureja subspicata Vis. growing in Croatia. Food Chem. 2006;96:2028.

Suharmiati, Maryani H. Khasiat dan Manfaat Daun Dewa \& Sambung Nyawa. (Jakarta, Indonesia: Agromedia Pustaka), 2003.

Tamokou JDD, Tala MF, Wabo HK, Kuiate JR, Tane P. Antimicrobial activities of methanol extract and compounds from stem bark of Vismia rubescens. J Ethnopharmacol. 2009;124:571-575.

Tshikalange TE, Meyer JJM, Hussein AA. Antimicrobial activity, toxicity and the isolation of bioactive compound from plants used to treat sexually transmitted diseases. J Ethnopharmacol. 2005;96:515-519.

Vardar-nl G, Candan F, Skmen A, Daferera D, Polissiou M, Skmen M, Dnmez E, Tepe B. Antimicrobial and antioxidantactivity of the essential oil and methanol extracts of Thymus pectinatus Fisch. et Mey. Var. pectinatus (Lamiaceae). J Agric Food Chem. 2003;51:63-67.

Voda K, Boh B, Vrtačnik M. A quantitative structure-antifungal activity relationship study of oxygenated aromatic essential oil compounds using data structuring and PLS regression analysis. J Mol Model. 2004;10:76-84.

Yuan SQ, Gu GM, Wei TT. Studies on the alkaloids of Gynura segetum (Lour.) Merr. Acta pharmaceutica Sinica. 1990;25:191197.

Zhu XF, Zhang HX, Raymond L. Phenolic compounds from the leaf extract of Artichoke (Cynara scolymus L.) and their antimicrobial activities. J Agric Food Chem. 2004;52:72727278 . 